\title{
STUDY OF REVERSIBILITY OF COERCIVITY UNDER HEAT TREATMENT IN PERMANENT MAGNETS
}

\author{
Alexey Lileev, Victoria Pinkas, Kristina Voronchihina, and Anton Gunbin \\ NUST “MISIS”, Moscow, Russia
}

\begin{abstract}
This article is aimed at observation all discussion and results that have ever been found about the phenomenon of reversibility of coercivity under heat treatments in permanent magnets including the latest researches. Despite the fundamental differences in the nature of coercivity as sensitive to structure property and magnetization reversal processes all works illustrate no changes in structure under heat treatment that causes doubts about this phenomenon.
\end{abstract}

\section{Introduction}

The phenomenon of reversibility of coercivity under heat treatments in permanent magnets have known for a long time. Short time heating of the magnets at a high temperature after the complete technological cycle leads to a sharp reduction of magnetic properties, especially the coercivity. Low-temperature aging reverses alloys to initial magnetic properties. Analysis of previous investigations and additional experiments show that reversibility of coercivity is characteristic of almost all magnets. This phenomenon occurs in almost all alloys for permanent magnets, despite the fundamental differences in the nature of coercivity as sensitive to structure property and magnetization reversal processes. Present work based on studies of changes and the reversibility of magnetic properties under different heat treatments attempted to explain this phenomenon in different magnetic alloys.

\section{Comparative study of reversibility of coercivity}

Reversibility of coercivity of the permanent magnets under heat treatments discovered in current research and previous works remains unclear and ambiguous because of many issues of this phenomenon at present. In current research, the results of studies and literature data describe the samples of alloys obtained from industrial enterprises using a standard, common technology, and the measurements were performed with standard equipment.

Table 1 Reversibility of coercivity under heat treatments in permanent magnets

\begin{tabular}{|c|c|c|c|c|c|}
\hline Year & Material & $\begin{array}{l}\text { Hc optimal } \\
\text { KA/m(kOe) }\end{array}$ & $\begin{array}{c}\text { Hc spoiling } \\
\text { KA/m (kOe) }\end{array}$ & $\begin{array}{c}\text { Hc reconditioning } \\
\text { KA/m (kOe) }\end{array}$ & Source \\
\hline 1964 & Alnico & $48(0.6)$ & $32(0.4)$ & $48(0.6)$ & {$[1]$} \\
\hline 1973 & Ticonal & $116(1.45)$ & $36(0.45)$ & $116(1.45)$ & {$[2]$} \\
\hline 1975 & $\mathrm{SmCo}_{5}$ & $1840(23.0)$ & $1240(15.0)$ & $1840(23.0)$ & {$[3]$} \\
\hline 1979 & $\mathrm{Sm}-\mathrm{Co}_{0}-\mathrm{Cu}-\mathrm{Fe}-\mathrm{Zr}$ & $1120(14.0)$ & $720(9.0)$ & $1120(14.0)$ & {$[4]$} \\
\hline 2014 & $\mathrm{Sm}\left(\mathrm{Co}_{0.65} \mathrm{Fe}_{0.26} \mathrm{Cu}_{0.07} \mathrm{Zr}_{0.02}\right)_{7}$ & $2360(29.5)$ & $96(1.2)$ & $2360(29.5)$ & {$[5]$} \\
\hline 2014 & $\mathrm{Nd}_{2} \mathrm{Fe}_{14} \mathrm{~B}\left(1050^{\circ} \mathrm{C}\right)$ & $1520(19.0)$ & $1190(14.9)$ & $1520(19.0)$ & {$[6]$} \\
\hline 2016 & $\mathrm{Nd}_{2} \mathrm{Fe}_{14} \mathrm{~B}\left(1000^{\circ} \mathrm{C}\right)$ & $1740(21.8)$ & $1247(15.7)$ & $1662(20.9)$ & present research \\
\hline 2015 & $\mathrm{Nd}_{2} \mathrm{Fe}_{14} \mathrm{~B}\left(900^{\circ} \mathrm{C}\right)$ & $1740(21.8)$ & $1340(16.9)$ & $1740(21.8)$ & {$[7]$} \\
\hline 2017 & $\mathrm{Nd}_{2} \mathrm{Fe}_{14} \mathrm{~B}\left(800^{\circ} \mathrm{C}\right)$ & $1740(21.8)$ & $1367(17.2)$ & $1740(21.8)$ & present research \\
\hline 2017 & $\mathrm{Nd}_{2} \mathrm{Fe}_{14} \mathrm{~B}\left(70{ }^{\circ} \mathrm{C}\right)$ & $1740(21.8)$ & $1332(16.7)$ & $1740(21.8)$ & present research \\
\hline 2017 & $\mathrm{FeCrCo}^{2}$ & $44(0.55)$ & $2.0(0.025)$ & $44(0.55)$ & present research \\
\hline
\end{tabular}


Table summarizes data for a reversible change of the coercivity of the magnets under heat treatments obtained on the various alloys with reference to authors (the coercivity in the initial condition - "Hc optimal", after high-temperature heating of the initial state - "Hc spoiling" and after the low temperature aging - " $\mathrm{Hc}$ reconditioning").

This table shows only values of the coercivity on the magnetization as this property is sensitive to structure and determined by the mechanism of magnetization reversal. High temperature range that leads to reduction of properties ('spoiling') and low temperature aging that reverses initial properties ('reconditioning') are described in details later. The essential point is the reversible changes of the coercivity, as the structure of the alloy is not changed reversibly by heat treatment. The aim of the present work is to analyse studies of magnetization reversal processes in real permanent magnets for the possibility of further improvement of technology.

The analysis starts with the system Fe-Co-Ni-Al-Ti (Alnico and ticonal), in which the coercivity is determined by the rotation process of the magnetization vector in the elongated single-domain particles of the ferromagnetic phase. Heating of the samples with coercivity $116 \mathrm{kA} / \mathrm{m}$ $(1.45 \mathrm{kOe})$ at a temperature of $800{ }^{\circ} \mathrm{C}$ for $1-3$ minutes causes it to reduce to $36 \mathrm{kA} / \mathrm{m}(0.45 \mathrm{kOe})$. Aging at 650 ${ }^{\circ} \mathrm{C}$ within 5 hours and $560{ }^{\circ} \mathrm{C}$ in 24 hours reverse of coercivity to the initial value.

In this case, the reversible changes ${ }_{1} \mathrm{H}_{\mathrm{C}}$ were about $70 \%$ connected with reversible local change in the composition of $\alpha_{1}$ and $\alpha_{2}$ - phases and possible atomic ordering in one of the phases [2], so the quantitative changes are not explained only by the composition changes. However, in these studies it is ignored the fact of changes in magnetostatic interaction between particles that is related to changes of the magnetic moment connected with changes in the composition of the phases.

In the magnets of system Fe-Co-Cr coercivity is also associated with the rotation process of the magnetization vector in single-domain particles. The coercivity after the full treatment cycle $-620{ }^{\circ} \mathrm{C} \quad 45$ minutes TMT (Thermomagnetic Tempering) and step aging $610^{\circ} \mathrm{C}$ in 2 hours, $580^{\circ} \mathrm{C}$ in 3 hours, $560^{\circ} \mathrm{C}$ in 4 hours and $540^{\circ} \mathrm{C}$ in 6 hours) is $44.9 \mathrm{kA} / \mathrm{m}$. The "spoiling" $\left(620{ }^{\circ} \mathrm{C}\right.$ for 15 minutes) reduces the coercivity to $0.6 \mathrm{kA} / \mathrm{m}$. Step aging reverse the coercivity to $43.7 \mathrm{kA} / \mathrm{m}$. Reversibility of 95 $\%$ of coercivity is not able to be explained by local changes of structure. Even accounting for the extended partition of particles, which is observed in these alloys does not eliminate the problem of understanding the phenomenon. These results were obtained for the first time and there was no a detailed study of the influence of temperature and duration of the "spoiling", but the result deserves attention.

In sintered magnets based on $\mathrm{SmCo}_{5}$ and $\mathrm{Nd}-\mathrm{Fe}-\mathrm{B}$ coercivity is determined by the difficulty of nucleation in highly anisotropic phase. In [3] a sintered permanent magnet $\mathrm{SmCo}_{5}$ with the coercivity $1840 \mathrm{kA} / \mathrm{m}(23.0$ kOe) was heated to a temperature $700{ }^{\circ} \mathrm{C}$ for 1 minute that reduced the coercivity to $1240 \mathrm{kA} / \mathrm{m}(15.0 \mathrm{kOe})$. Aging at $400{ }^{\circ} \mathrm{C}$ for 60 minutes reverses the value of the coercivity. Reversible changes was about $30 \%$.
In [6] "spoiling" sintered magnets $\mathrm{Nd}-\mathrm{Fe}-\mathrm{B}$ of different composition at high temperature $1050{ }^{\circ} \mathrm{C}$ within 30 minutes was performed, and then spent the cooling at $500{ }^{\circ} \mathrm{C}$ for 1 hour. Reversible changes of the coercivity were about $30 \%$.

In [7] and in subsequent studies, experiments of 'spoiling' were performed at temperatures of 1000, 900, 800 and $700{ }^{\circ} \mathrm{C}$. Aging at $500{ }^{\circ} \mathrm{C}$ for 1 hour reversed the value of the coercivity to the initial. Reversible changes of the coercivity were about $30 \%$.

It is difficult to explain the reversibility of changes of structural properties in single-phase materials. In several papers it is assumed that the process of aging at $500{ }^{\circ} \mathrm{C}$ makes grain boundaries smooth which leads to increase of coercivity. However, it is difficult to suppose explanation of the phenomenon of reversibility. There is hypothesis that excess phases occur transformation at the boundary of cell phase [8].

The most interesting results and discussions are related to the reversibility of coercivity that exists in system of Sm-Co-Fe-Cu-Zr, in which the coercivity is determined by pinning of domain walls at the boundaries of cells phase 2:17. The boundary cells similar to phase 1:5 [9]. In [5] a study of the "spoiling" at a temperature of $800{ }^{\circ} \mathrm{C}$ within 16 hours at which the structure of the alloy is formed, followed by controlled cooling from $400{ }^{\circ} \mathrm{C}$ to $800{ }^{\circ} \mathrm{C}$ for 4 hours. Heating of the samples with coercivity of 2360 $\mathrm{kA} / \mathrm{m}(29.5 \mathrm{kOe})$ for 5 minutes reduces the coercivity to $96 \mathrm{kA} / \mathrm{m}$ (1.2 kOe). Controlled cooling reverses coercivity and a reversible change is $95 \%$ or almost 30 -fold change compared to the state with zero coercivity. It is important to mention that there are no changes in value of reversal coercivity with increasing aging time at $800{ }^{\circ} \mathrm{C}$ up to 22 hours.

In [9-11] detailed chemical analysis was performed with using $3 \mathrm{D}$ atom probe of the boundary-phase 1:5 in the state after rapid cooling from $800{ }^{\circ} \mathrm{C}$ and after controlled cooling. It is shown that on the border there is a redistribution of $\mathrm{Cu}$ and $\mathrm{Zr}$, and changes the nature of the distribution of the components. In [11] the calculation of the distribution constants of anisotropy in the phase boundary takes into account the changing nature of the distribution of the components. However, the question how the changing nature of distribution of the constants of anisotropy can affect multiple changes in the coercivity is not solved.

As can be seen from the listed examples of reversible changes of the coercivity under heat treatments, many questions are related not only to the formation of the alloy structure, but also to the nature of coercivity and magnetization reversal processes.

\section{References}

[1] A.S. Ermolenko. Diss. candidate of ph. and math. sciences, Institute of metal physics, Sverdlovsk USSR (1964)

[2] A.S.Lileev, V.P.Menushenkov, V.I. Sumin, PhMM, (1973) 183-186.

[3] B.G. Livshitz, A.S. Lileev, V.P. Menushenkov, IEEE Trans. Magn., (1975) 1673 - 1675. 
[4] V.I. Habarov, T.Z. Puzanova, Ya.S. Shur, PhMM, (1979) 921-926.

[5] A.S. Lileev, O.A. Arinicheva, M. Reissner, F. Kubel, V. A. Sein, J. MSHT, 56, (2016) 591-594.

[6] T.G. Woodcock, F. Bittner, T. Mix, JMMM, 360 (2014) 157-164..

[7] Labour Digest VI INTERNATIONAL CONFERENCE Functional nanomaterials and high-purity substances. Suzdal, Russia (2016).

[8] V.P. Menushenkov, A.G. Savchenko, JMMM, 272 (2004) 1891-1893.
[9] X.Y. Xiong, T. Ohkubo, T. Koyama, K. Ohashi, Y. Tawara, K. Hono, Acta Mater, 52, (2004) 737-748.

[10] O.Gutfleisch, K.-H. Müller, K. Khlopkov, M. Wolf, A. Yan, R. Schäfer, T. Gemming, L. Schultz, Acta Mater, 54, (2006) 997-1008.

[11] H. Sepehri-Amin, J. Thielsch, J. Fischbacher, Acta Mater, 126, (2017) 1-10. 